\title{
ASSESSMENT OF THE LEVEL OF ANTHROPOGENIC CONTRIBUTIONS TO HEAVY METAL POLLUTION ON SOME ABANDONED WASTE-DUMP SITES IN THE YENAGOA METROPOLIS IN BAYELSA STATE
}

\author{
Lewis Igo \\ Department of Chemical Sciences, Niger Delta University, Wilberforce Island, P. M. B. 071, Bayelsa State, Nigeria \\ Erepamowei Young \\ Department of Chemical Sciences, Niger Delta University, Wilberforce Island, P. M. B. 071, Bayelsa State, Nigeria
}

Timi Tarawou

Department of Chemical Sciences, Niger Delta University, Wilberforce Island, P. M. B. 071, Bayelsa State, Nigeria Corresponding author: Erepamowei Young; Telephone \# +234 (0) 8065591763; E- mail address: erekomu2004@ yahoo.co.uk.

\author{
DOI: 10.31364/SCIRJ/v6.i11.2018.P1118577 \\ http://dx.doi.org/10.31364/SCIRJ/v6.i11.2018.P1118577
}

\begin{abstract}
Industrial revolution has caused a great increase in the heavy metal pollution of soils with no exception of soils at waste dump sites. However, anthropogenic sources are not the only sources of heavy metal pollution, hence this research work was aimed at assessing the anthropogenic contributions to metal pollution on some abandoned waste dump sites in the Yenagoa metropolis in Bayelsa State. Soils samples were collected from sites and analyzed using flame atomic absorption spectrometer. Pollution indices were calculated from the analytical results. Concentrations ranged $(0.044 \mathrm{mg} / \mathrm{kg}-2.048 \mathrm{mg} / \mathrm{kg}$, except Fe), contamination factor $(0.274-4.604)$, pollution load index (1.06 - 1.741), ecological risk index (71.61 - 167.67), ecological risk coefficient (0.72 - 138.12), geo-accumulation (- 0.057 - 1.181), Nemerow multi-factor (0.34 - 3.65), pollution contamination indices $(0.35$ - 3.87), modified degree of contamination indices (1.11 - 2.41), contamination degree indices $(7.40$ - 14.50), enrichment factor $(0.497-7.435)$. Generally, these values indicate that the abandoned waste dump sites are only minimally polluted and may not adversely affect farming activities. The results are also consistent with the low level of industrialization of Bayelsa State.
\end{abstract}

Keyword: Abandoned, heavy metal, pollution, index, waste

\section{INTRODUCTION}

Soil is a dynamic resource for the survival of human life and due to its complex matrix; it is the principal receiver of persistent contaminants such as heavy-metals (Luo et al., 2007). Every soil comprises some natural quantities of heavy-metals, at concentrations called backgrounds. The magnitude of a metal's background depends upon the composition of the parent rock material from which the soil was derived (Scazzola et al., 2003). Human activities that add waste material to the soils also influence its metal concentration (Pastor, Hernandez, 2012).

Soil can be contaminated with waste (either solid or liquid), in addition to its land use impact, can cause water and soil pollution as well as soil erosion and other environmental problems. However, heavy-metals are of considerable environmental concern due to their 
toxicity, wide sources, non-biodegradable properties and accumulative behaviors (Yu et al., 2008, Gong et al., 2008, Homa et al., 2003).

Soil can be polluted with heavy-metals via industrial, agricultural and domestic activities (Fytianos et al. 2001). However, sources related to industrialization are central sources of heavy-metal to soils (Stafilov et al., 2010).

However the spread of such pollution is also a major concern; heavy-metals can be transported long distances via atmospheric particulates after liberation into the environment (Wu et al., 2010). A portion of metals in the atmosphere may be transferred to soils by atmospheric deposition ( $\mathrm{Lu}$ et al., 2010). The continual disposal of municipal waste on the soil may lead to increase in heavy metals in the soil surface water that would be inimical to deep feeding plants. Heavy metals such as arsenic, cadmium, lead, chromium, nickel, cobalt and mercury are concerned primarily because of their ability to harm the soil organisms, plants, animals and human beings. More emphatic are untreated dumplings that rapidly increase soil toxicity, making large area dump sites potentially hazardous for agricultural purposes. Dump site fields therefore can be seen to provide farmers with fertile plots for cultivation of vegetables and other surface feeder crops.

Most studies of metals leaching in soil columns or field investigations conclude that trace metals are strongly bound to topsoil (Sukkeriyah et al., 2005). The dump sites also acts as breeding grounds for disease vectors causing serious health problems in the neighborhood.

Some contamination by heavy metals is of most important apprehension throughout the industrialized world (Hinojosa et al., 2004). Heavy metal pollution not only result in adverse effects on various parameters related to plant quality and yield but also cause changes in the size, composition and activity of the microbial community (You H, et al., 2003). The adverse effects of heavy metals on soil biological and biochemical properties are well documented. The soil properties, i.e., organic matter, clay contents and pH have major influences on the extent of the effects of metals on biological and biochemical properties.

The effect of different concentrations of heavy metals on soil microbial biomass was studied and conclusions drawn up; if the concentration of heavy metals in the soil was three time above the environment standard, established by the European Union, it could inhibit microbial biomass. The low concentrations of heavy metals could stimulate microbial growth and increase microbial biomass, while high concentration could decrease soil microbial biomass significantly.

Some of these heavy metals i.e. $\mathrm{As}, \mathrm{Cd}, \mathrm{Hg}, \mathrm{Pb}$, and $\mathrm{Se}$ are not essential for plant growth, since they do not perform any known physiological function in plants. Others such as $\mathrm{Co}, \mathrm{Cu}, \mathrm{Fe}, \mathrm{Mn}, \mathrm{Mo}, \mathrm{Ni}$ and $\mathrm{Zn}$ are essential elements required for normal growth and metabolism of plants, but these elements can easily lead to poisoning when their concentration is greater than optimal values (Rascio 
et al., 2011). The use of compost to improve agricultural yield without caring about the possible negative effects might be a problem since the waste composts are most applied to improve soils used to grow vegetables. Considering the edible part of the plant in most vegetable species, the risk of transference of heavy metals from soil to humans should be a matter of concern (Jordao et al., 2007).

Uptake of heavy metals by plants and subsequent accumulation along the food chain is a potential threat to animal and human health. The absorption by plant rots is one of the main routes of entrance of heavy metals in food chain (Jordao et al., 2007).

Heavy metal accumulation in plants depends upon plant species and the efficiency of different plants in absorbing metals. This is evaluated by either plant uptake or soil to plant transfer factors of the metals (Khan et al., 2008). Heavy metals are potentially toxic and phytoxicity for plants may result in chlorosis, weak plant growth, yield depression, and may even be accompanied by reduced nutrient uptake, disorders in plant metabolism and reduced ability to fixate molecular nitrogen in leguminous plants, impairment to enzymes (Xue et al., 2015). In this present study is to assess the heavy metal contamination in top soil of some selected waste dump site in Bayelsa State. Specific objective of this study include the assessment of the level of heavy metal concentration in the top soil from different abandoned waste dump sites in Bayelsa State and to evaluate the pollution levels using different pollution indices which include, contamination factor, pollution load index, heavy metals potential ecological risk coefficient $\left(E_{r}^{i}\right)$ and potential ecological index, geo-accumulation index, nemerow multi-factors or Nemerow Integrated pollution value, pollution contamination index, modified degree of contamination and contamination degree index, enrichment factor.

The research work was designed to assess the level of contribution of anthropogenic sources to the heavy metal pollution on some abandoned waste dump sites by subjecting concentration data to pollution-indication methods such as contamination factor (CF), degrees of ecological risk, potential Contamination index, Modified degree of contamination, Enrichment factor, geo-accumulation index, Nemerow multi-factor.

\section{MATERIALS AND METHODS}

\section{Study Area}

Yenagoa is geographically located between latitude $4^{\circ} 47^{1}$ and $5^{\circ} 11^{1} \mathrm{~N}$ and Longitude $6^{\circ} 01^{1}$ and $6^{\circ} 24^{1}$ and lies within 31 and $32 \mathrm{~N}$ of World Geodetic System 1984 "WGS84" (Ndiwarri, 2004). The town is located in a humid tropical wetland area with mean annual rainfall of about $2539 \mathrm{~mm}$ and an average temperature of $26.2^{\circ} \mathrm{C}$.

\section{Sampling, Sample description, and Preparation}

\section{Sampling}


Three replicates soil samples $(15 \mathrm{~cm}$ depth) were collected from three abandoned waste dump sites; one from each community: Azikoro, Etegwe, and Biogbolo, all in Yenagoa (Bayelsa State). For each site, a control sample was also collected, a 100 meters away from each ump site. The soil samples were collected in February 2017 at depths of 0 to $15 \mathrm{~cm}$ using soil Auger. Samples were put in polyethylene bags, sealed and labeled properly.

\section{Sample description}

In most samples, the soil $\mathrm{pH}$ ranged from 6.13 to 7.84 and in one of the samples (collected from the Azikoro village dump site) the mean $\mathrm{pH}$ value was 7.05 (Table 1$)$.

The percentage organic matter and percentage organic carbon ranged from $1.89-6.28$, and $2.18-5.41$ respectively for the sites under investigation.

Table 1. $\mathrm{pH}$ values of the soil samples from waste dump sites

\begin{tabular}{lllll}
\hline Sites & $\mathbf{1}$ & $\mathbf{2}$ & $\mathbf{3}$ & Mean \\
\hline Etegwe & 6.46 & 7.14 & 6.14 & 6.59 \\
Azikoro village & 6.13 & 7.17 & 7.84 & 7.05 \\
Biogbolo & 7.29 & 7.52 & 7.40 & 7.40 \\
\hline
\end{tabular}

Measurement of Conductivity

The mean conductivity values ranged between 1.14 to $1.22 \mu \mathrm{Scm}^{-1}$ in the soil samples of the different abandoned waste dump sites (Table 2). However, the conductivity values of the topsoil of the waste dump sites were all between the normal range $0-200 \mu \mathrm{Scm}^{-1}$.

Table 2. Conductivity $\left(\mu \mathrm{Scm}^{-1}\right)$ values on the soil from the waste dumps sites

\begin{tabular}{lllll}
\hline Sites & $\mathbf{1}$ & $\mathbf{2}$ & $\mathbf{3}$ & Mean $\left(\boldsymbol{\mu S \mathbf { S c m } ^ { - 1 } )}\right.$ \\
\hline Etegwe & 1.14 & 1.19 & 1.21 & 1.18 \\
Azikoro village & 1.18 & 1.15 & 1.12 & 1.15 \\
Biogbolo & 1.16 & 1.13 & 1.13 & 1.14 \\
\hline
\end{tabular}

\section{Sample preparation and AAS analysis}

The samples were spread out and placed in a designed air-dried special room in the laboratory for seventeen days. Then the samples were ground using mortar and pestle and sieved through a $2 \mathrm{~mm}$ sieve to get fine powdered samples and stored in plastic cover plate at room temperature.

The soil samples were digested; $2.0 \mathrm{~g}$ of sample was mixed with $30 \mathrm{~mL}$ of Aqua regia $\left(3: 1\right.$ of $\left.\mathrm{HNO}_{3}: \mathrm{H}_{2} \mathrm{SO}_{4}\right)$, heated on a hot plate inside fume cupboard. The digested samples were filtered through Watchman filter paper; the filtrate was diluted with 50 mL of distilled water. The diluted samples were taken for heavy metal determination using Atomic Absorption Spectrophotometer (AAS). 


\section{METHODS FOR ASSESSING THE LEVEL OF ANTHROPOGENIC CONTRIBUTIONS TO METAL POLLUTION IN SOIL (POLLUTION INDICES)}

In this present study, contamination factor (CF), heavy metal potential ecological risk coefficient and potential ecological index, pollution contamination index, modified degree of contamination and contamination degree index, and enrichment factor (EF) were used to assess the metal pollution levels in the soil samples. Reference values (Earth crust averages) of the studied metals which were used as background values were taken in different location were no activities are taken placed.

\section{Contamination Factor $(\mathbf{C F})$}

The contamination factor is an expression of the level of metal contamination in the surface sediment. It is the quotient attained by division of the concentration of each metal in the soil by the reference value (Hakanson, 1980; and Maanan et al., 2014). It is given by the formula;

$$
\mathrm{CF}=\frac{C_{\text {metal }}}{C_{\text {background }}}
$$

Where $C_{\text {metal }}$ is the concentration of a given metal in the sediment and $C_{\text {background }}$ is the metal concentration of a control sample.

Table 3. Classification based on contamination factor (CF)

\begin{tabular}{ll}
\hline CFs value Scale & Classification \\
\hline $\mathbf{1}$ and less & No contamination \\
$\mathbf{1 - 2 . 0}$ & Suspected \\
$\mathbf{2 - 3 . 5}$ & Slight \\
$\mathbf{3 . 5 - 8}$ & Moderate \\
$\mathbf{8 - 2 7 . 0}$ & Severe \\
$\mathbf{2 7}$ and above & Extremely \\
\hline
\end{tabular}

\section{Heavy Metal Potential Ecological Risk Coefficient and Potential Ecological Index}

Potential ecological risk index method advanced by Swedish Scholar Hakanson, according to the characteristic of heavy metal and its environment behavior, is an approach to evaluate the heavy metal contamination from the perspective of sedimentology.

It does not only consider heavy metal level in the soil, but also associates ecological and environmental effects with toxicology, and evaluates pollution using comparable and equivalent property index grading method. The potential ecological risk related to individual pollution coefficient, heavy metal toxicity response coefficient, and its formula is as follows: $R I=\sum E_{r}^{i}$

$$
E_{r}^{i}=T_{r}^{i} X C_{f}^{i}
$$




$$
C_{f}^{i}=\frac{C_{\text {surface }}^{i}}{C_{n}^{i}}
$$

Where $E_{r}^{i}$ is potential ecological risk individual coefficient, $T_{r}^{i}$ is toxicity response coefficient of a certain kind of metal toxicity using standard heavy metal toxicity coefficient developed by Hakanson (1980) as reference, in accordance with the normalized toxic response factor of 30, 5, 5, 5, 2 and 1 respectively for $\mathrm{Cd}, \mathrm{Cu}, \mathrm{Pb}, \mathrm{Ni}, \mathrm{Cr}$, and $\mathrm{Zn}$.

$C_{f}^{i}$ is the accumulating coefficient of element $i$ and $\mathrm{RI}$ is the potential ecological risk index.

Table 4. Classification based on ecological risk

\begin{tabular}{ll}
\hline $\mathbf{R i}$ or $\boldsymbol{E}_{r}^{i}$ & Ecological Pollution degree \\
\hline $\boldsymbol{E}_{r}^{i}<\mathbf{4 0}$ or $\mathbf{R i}<\mathbf{1 5 0}$ & Low ecological risk for the sediment \\
$\mathbf{4 0} \leq \boldsymbol{E}_{r}^{i}<\mathbf{8 0}$ or $150 \leq \mathbf{R i}<\mathbf{3 0 0}$ & Moderate ecological risk for the soil \\
$\mathbf{8 0} \leq \boldsymbol{E}_{r}^{i}<\mathbf{1 6 0}$ or $\mathbf{3 0 0} \leq \mathbf{R i}<\mathbf{6 0 0}$ & Considerable ecological risk for the soil \\
$\mathbf{1 6 0} \leq \boldsymbol{E}_{r}^{i}<\mathbf{3 2 0}$ or $\mathbf{6 0 0} \leq \mathbf{R i}$ & Very high ecological risk for the soil \\
\hline
\end{tabular}

\section{Potential Contamination Index}

The potential contamination index (Cp) can be evaluated by the equation (Dauvalter, Rognerud, 2001; Maanan et al., 2014).

$$
C p=\frac{M_{\text {sample max }}}{M_{\text {reference }}}
$$

Where $M_{\text {sample max }}$ is the maximum concentration of an element in the soil, and $M_{\text {reference }}$ is the value of the same element in a reference soil. Cp value were explained as proposed by Dauvalter and Rognerud (2001), where $\mathrm{Cp} \leq 1$ indicates low pollution; $1<\mathrm{Cp}$ $\leq 3$ is moderate pollution; and $\mathrm{Cp}>3$ is severe or very severe pollution.

Table 5. Concentration of the Elements

\begin{tabular}{lllllll} 
Elements: & Cd & Cu & Pb & Ni & Cr & Zn \\
Max. & 0.069 & 0.139 & 1.506 & 0.741 & 1.420 & 0.614 \\
reference & 0.032 & 0.092 & 1.071 & 0.410 & 0.907 & 0.523 \\
\hline
\end{tabular}

Table 6. Classification based on Potential Contamination index

\begin{tabular}{lll}
$\begin{array}{l}\text { Grade } \\
\text { division }\end{array}$ & Cp value & Pollution level \\
\hline $\mathbf{1}$ & $\mathrm{Cp} \leq 1$ & Low pollution \\
$\mathbf{2}$ & $1<\mathrm{Cp} \leq 3$ & Moderate pollution \\
$\mathbf{3}$ & $\mathrm{Cp}>3$ & Severe or very severe pollution \\
\hline
\end{tabular}




\section{Contamination Degree (Cd)}

In order to simplify contamination control, Hakanson (1980) suggested a method utilizing a diagnostic tool named the contamination degree (Cd). Cd was calculated as the sum of the CF for each sample: $C d=\sum_{i=1}^{i=n} C F$. In accordance with Hakanson $(1980)$; $\mathrm{Cd}<6$ indicates a low degree of pollution; $6<\mathrm{Cd}<12$ is a moderate pollution; $12<\mathrm{Cd}<24$ is a considerable degree of pollution; and $\mathrm{Cd}$ $>24$ is high degree of pollution indicating serious anthropogenic pollution.

\section{Modified degree of contamination}

The modified degree of contamination $(\mathrm{mCd})$ was presented to approximate the complete degree of pollution (Abrahim, Parker, 2008; Maanan et al., 2014):

$$
m C d=\frac{\sum_{i=1}^{i=n} C F}{n}
$$

Where $\mathrm{n}$ is the number of examined elements, $i$ is the $i$ th pollution and CF is the contamination factor.

$\mathrm{mCd}<1.5$ is nil to a very low degree of pollution;

$1.5 \leq \mathrm{mCd}<2$ indicates a low degree of pollution;

$2 \leq \mathrm{mCd}<4$ indicates a moderate degree of pollution;

$4 \leq \mathrm{mCd}<8$ indicates a high degree of pollution;

$8 \leq \mathrm{mCd}<16$ indicates a very high degree of pollution;

$16 \leq \mathrm{mCd}<32$ indicates an extremely high degree of pollution;

$\mathrm{mCd} \leq 32$ indicates an ultra-high degree of pollution.

\section{Enrichment Factor}

Enrichment factor is one of the indicators most often used for estimating anthropogenic inputs (Gonzales-Macias et al., 2006, Liu Wx et al., 2003, and Louri et al., 2011). Using this technique, the sediment's EF ratio can be used as a pollution index by comparing the concentrations of selected metals to the background levels of metal in sediments or suspended particulate matter from local or worldwide rivers. The advantage of using measurement concentration of local sediments as background values is that they can be better for comparison. The widely used elements for normalization are $\mathrm{Al}$ (Zhang et al., 2009, Kwokal et al., 2002) and Fe (Ghrefat et al., 2006, and Cevik et al., 2009).

EF is important indicators that quantitatively assess the levels and sources of heavy metal pollution. 


$$
E F=\frac{(M / F e)_{\text {samle }}}{\left({ }^{M} / F e\right)_{\text {background }}}
$$

Where $\left({ }^{M} / F e\right)_{\text {samle }}$ is the sample value of metal of interest to $\mathrm{Fe}$,

$\left({ }^{M} / \mathrm{Fe}\right)_{\text {background }}$ is the background value of metal to Fe.

Iron was chosen as the element of normalization because natural sources $(1.5 \%)$ vastly dominate its input.

Table 7. Classification based on Enrichment factor (EF)

\begin{tabular}{ll}
\hline EF value & Contamination degree \\
\hline$<\mathbf{1}$ & No enrichment \\
$\mathbf{2}$ & Deficiency to minimal enrichment \\
$\mathbf{2 - 5}$ & Moderate enrichment \\
$\mathbf{5 - 2 0}$ & Significant enrichment \\
$\mathbf{2 0 - 4 0}$ & Very high enrichment \\
$>\mathbf{4 0}$ & Extremely high enrichment \\
\hline
\end{tabular}

\section{Geo-accumulation index $\left(I_{g e o}\right)$}

The geo-accumulation index $\left(I_{g e o}\right)$ was utilized to evaluate the degree of element pollution in soils by balancing the present with original concentrations; however it is hard to find original soil.

The $I_{g e o}$ values of a sample can be evaluated with the following equation:

$$
I_{\text {geo }}=\log _{2}\left[C_{i} /(1.5 B i)\right]
$$

Where $C_{i}$ the current elements concentration in the soil samples and $B_{i}$ is the geochemical reference value as defined by Taylor and Mclennan (1995). The modified coefficient, constant 1.5 was utilized to characterize the effect of accumulation and geological characteristic and determine the consequence of human activities. $I_{g e o}$ can be separated into seven classes (Muller, 1969).

Table 8. Classification based on geo-accumulation index

\begin{tabular}{lll}
\hline Igeo value & Class & Sediment Quality \\
\hline$\leq \mathbf{0}$ & 0 & Unpolluted \\
$\mathbf{0}-\mathbf{1}$ & 1 & From unpolluted to Moderate polluted \\
$\mathbf{1}-\mathbf{2}$ & 2 & Moderate polluted \\
$\mathbf{2}-\mathbf{3}$ & 3 & From moderate to Strongly polluted \\
$\mathbf{3}-\mathbf{4}$ & 4 & Strongly polluted \\
$\mathbf{4}-\mathbf{5}$ & 5 & From strongly to extremely polluted \\
$\mathbf{> 6}$ & 6 & Extremely polluted \\
\hline
\end{tabular}




\section{The Nemerow multi-factor index}

As The sub-index can be used to calculate the single factor in multi-factor comprehensive pollution indices of soil heavy metals (Li et al., 2003 and Soldecilla et al., 1992). In addition to synthetically and objectively reflecting the degree of contamination of different elements, the comprehensive contamination index is able to highlight the effects of high concentrations of contaminant on environmental soil quality.

To assess the degree of heavy-metal contamination, pollution index $\left(P_{i}\right)$ for each metal and Nemerow multi-factor or integrated pollution index $\left(P_{c}\right.$ or NIPI) (Yang et al., 2011), the single contamination index

$$
P_{i}=C_{i} / S_{i}
$$

Where $P_{i}$ is the contamination index of soil contaminants $i$ : $\mathrm{C}_{i}$ is the measured value of soil contaminants $i$ in $\mathrm{mg} / \mathrm{kg}$, and $S_{i}$ is the background value of the soil contaminants $i$ in $\mathrm{mg} / \mathrm{kg}$.

The soil is not contaminated when $P_{i} \leq 1$, but is contaminated when $P_{i}>1$, and the higher the $P_{i}$, the more serious the soil contamination.

The Nemerow multi-factor index, $P_{c}$

$P_{c}=\left\{\left[\left(C_{i} / S_{i}\right)_{\text {ave }}^{2}+\left(C_{i} / S_{i}\right)_{\max }^{2}\right] / 2\right\}^{1 / 2}$

Where $P_{c}$ is the comprehensive contamination index of the soil contaminants, $\left({ }_{i} / S_{i}\right)$ ave is the average value of the pollution index of soil contaminants, and $\left(C_{i} / S_{i}\right)_{\max }$ is the maximum value of the single contamination index.

Table 9. Classification based on Nemerow multi-factor value

\begin{tabular}{llll}
\hline $\begin{array}{l}\text { Grade } \\
\text { division }\end{array}$ & Pc & $\begin{array}{l}\text { Contamination } \\
\text { level }\end{array}$ & Contamination degree \\
\hline $\mathbf{1}$ & $\mathrm{Pc} \leq 0.7$ & Save & Clean \\
$\mathbf{2}$ & $0.7 \leq \mathrm{Pc} \leq 1$ & Alert & Still clean \\
$\mathbf{3}$ & $1<\mathrm{Pc} \leq 2$ & light & Soil slightly contaminated; \\
$\mathbf{4}$ & $2<\mathrm{Pc} \leq 3$ & moderate & Moderately contaminated \\
$\mathbf{5}$ & $\mathrm{Pc}>3$ & Severely & Severely contaminated \\
\hline
\end{tabular}

\section{RESULTS AND DISCUSSION}

\section{Concentration of heavy metals in Etegwe abandoned waste-dump site}


The metal concentrations observed at each sampling site in this study are shown in Table 10 . The metal contents ranged over the following concentration: $\mathrm{Cd}(0.111-0.139 \mathrm{mg} / \mathrm{kg}), \mathrm{Cu}(0.248-0.292 \mathrm{mg} / \mathrm{kg})$, and $\mathrm{Pb}(0.288-0.389 \mathrm{mg} / \mathrm{kg}), \mathrm{Ni}(0.198-0.691 \mathrm{mg} / \mathrm{kg}), \mathrm{Cr}$ $(1.788-1.874 \mathrm{mg} / \mathrm{kg}), \mathrm{Zn}(1.398-1.742 \mathrm{mg} / \mathrm{kg})$ and $\mathrm{Fe}(217.348-238.223 \mathrm{mg} / \mathrm{kg})$ respectively. The average concentrations of the metals were $0.125,0.269,0.347,0.487,1.839$ and 1.602 for $\mathrm{Cd}, \mathrm{Cu}, \mathrm{Pb}, \mathrm{Ni}, \mathrm{Cr}$ and $\mathrm{Zn}$; following the order: $\mathrm{Cr}>\mathrm{Zn}>\mathrm{Ni}>\mathrm{Pb}>\mathrm{Cu}>$ Cd.

\section{Concentration of Heavy Metals in Azikoro Village abundant Waste Dump Site}

The metal concentrations for each sampling site are shown in Table 10. Metal contents ranged over the intervals: Cd (0.109-0.121 $\mathrm{mg} / \mathrm{kg}) ; \mathrm{Cu}(0.278-0.364 \mathrm{mg} / \mathrm{kg}) ; \mathrm{Pb}(0.249-0.317 \mathrm{mg} / \mathrm{kg}) ; \mathrm{Ni}(0.619-0.640 \mathrm{mg} / \mathrm{kg}) ; \mathrm{Zn}(0.237-0.452 \mathrm{mg} / \mathrm{kg}) \mathrm{and} \mathrm{Fe}(176.289-$ $226.356 \mathrm{mg} / \mathrm{kg}$ ) respectively. The mean concentration of the metals were $0.128,0.316,0.283,0.628,1.693 \mathrm{and} 0.373 \mathrm{for} \mathrm{Cd}, \mathrm{Cu}, \mathrm{Pb}$, $\mathrm{Ni}, \mathrm{Cr}$ and $\mathrm{Zn}$; defining this order in magnitude: $\mathrm{Cr}>\mathrm{Ni}>\mathrm{Zn}>\mathrm{Cu}>\mathrm{Pb}>\mathrm{Cd}$.

\section{Concentration of Heavy Metals in Biogbolo abandoned waste Dump Site}

The heavy metal concentrations, ranging and averages in the soil samples are shown in Table 10. The metal concentrations were found in the following ranges, $\mathrm{Cd}: 0.036-0.092 \mathrm{mg} / \mathrm{kg}$; $\mathrm{Cu}: 0.237-0.272 \mathrm{mg} / \mathrm{kg}$; $\mathrm{Pb}: 0.765-1.252 \mathrm{mg} / \mathrm{kg} ; \mathrm{Ni}: 0.499-0.663 \mathrm{mg} / \mathrm{kg}$; $\mathrm{Cr}$ : 1.516-1.658 mg/kg; Zn: $1.394-1.503 \mathrm{mg} / \mathrm{kg}$; and Fe: $184.216-253.727 \mathrm{mg} / \mathrm{kg}$ respectively. While mean concentration were 0.065 , 0.254, 0.943, 0.57, 1.573 and 1.441 for $\mathrm{Cd}, \mathrm{Cu}, \mathrm{Pb}, \mathrm{Ni}, \mathrm{Cr}$ and $\mathrm{Zn}$. The mean concentration values decreases from $\mathrm{Cr}$ to $\mathrm{Cd}$ as follows: $\mathrm{Cr}>\mathrm{Zn}>\mathrm{Pb}>\mathrm{Ni}>\mathrm{Cu}>\mathrm{Cd}$.

Table 10. The concentration of heavy metals in abandoned waste-dump sites

\begin{tabular}{llllllll}
\hline $\begin{array}{l}\text { Sampling } \\
\text { Point }\end{array}$ & \multicolumn{2}{l}{ Elements } & & & & & \\
Etegwe & Cd & Cu & Pb & Ni & Cr & Zn & $\mathbf{F e}^{*}$ \\
Mean & & & & & & & \\
Max & 0.125 & 0.269 & 0.347 & 0.487 & 1.839 & 1.602 & 226.676 \\
Min & 0.139 & 0.292 & 0.389 & 0.691 & 1.874 & 1.742 & 238.223 \\
Azikoro village & 0.111 & 0.248 & 0.288 & 0.198 & 1.788 & 1.398 & 217.348 \\
Mean & 0.128 & 0.316 & 0.283 & 0.628 & 1.693 & 0.373 & 201.82 \\
Max & 0.121 & 0.364 & 0.317 & 0.64 & 1.745 & 0.452 & 226.356 \\
Min & 0.109 & 0.278 & 0.249 & 0.619 & 1.711 & 0.237 & 176.289 \\
Biogbolo & & & & & & & \\
Mean & 0.065 & 0.254 & 0.943 & 0.570 & 1.573 & 1.441 & 222.475 \\
Max & 0.092 & 0.272 & 1.252 & 0.663 & 1.658 & 1.503 & 253.727 \\
Min & 0.036 & 0.237 & 0.765 & 0.499 & 1.516 & 1.394 & 184.216 \\
\hline
\end{tabular}

\section{The Concentration of Heavy Metal in Background Study}

The heavy metal concentrations for the background study are shown in Table 11. The metal content was found in the following intervals: $\mathrm{Cd}(0.027-0.04 \mathrm{mg} / \mathrm{kg}) ; \mathrm{Cu}(0.061-0.109 \mathrm{mg} / \mathrm{kg}) ; \mathrm{Pb}(0.938-1.239 \mathrm{mg} / \mathrm{kg}) ; \mathrm{Ni}(0.327-0.459 \mathrm{mg} / \mathrm{kg}) ; \mathrm{Cr}(0.79-0.99 \mathrm{mg} / \mathrm{kg})$; 
Zn (0.358-0.68 mg/kg); and Fe (504.448-521.626 mg/kg). The mean background value concentrations were 0.032, 0.092, 1.071, 0.41, 0.907, 0.523 and 514.287 for $\mathrm{Cd}, \mathrm{Cu}, \mathrm{Pb}, \mathrm{Ni}, \mathrm{Cr}, \mathrm{Zn}$ and $\mathrm{Fe}$ respectively. The background concentration decreases as follows: $\mathrm{Pb}>\mathrm{Cr}$ $>\mathrm{Zn}>\mathrm{Ni}>\mathrm{Cu}>\mathrm{Cd}$.

Table 11. The Background concentration of abandoned waste dump sites

\begin{tabular}{llllllll}
\hline Sampling & Elements & & & & & & \\
Point & Cd & Cu & Pb & Ni & Cr & Zn & $\mathbf{F e}^{*}$ \\
UPL 1 & 0.03 & 0.109 & 0.938 & 0.327 & 0.99 & 0.532 & 521.626 \\
UPL 2 & 0.027 & 0.108 & 1.036 & 0.459 & 0.973 & 0.68 & 516.789 \\
UPL 3 & 0.04 & 0.061 & 1.239 & 0.444 & 0.76 & 0.358 & 504.448 \\
Mean & 0.032 & 0.092 & 1.071 & 0.41 & 0.907 & 0.523 & 514.287 \\
\hline
\end{tabular}

Replicates sampling sites: UPL 1, UPL 2, and UPL 3

\section{Contamination Factor (CF) In Etegwe Waste Dump Sites}

The highest average contamination factor was found in $\mathrm{Cd}$ of 3.926, which indicates moderate contamination (Table 12). $\mathrm{Zn}, \mathrm{Cu}$ and Cr have average values of 3.062, 2.923 and 2.027 respectively, which indicate slight contamination in the soil. Ni has value of 1.187 , which indicates suspected contamination, but $\mathrm{Pb}$ has no contamination in the soil.

\section{Contamination factor (CF) in Azikoro village waste dump site}

Table 12 shows the contamination factors for metals in Azikoro site. The highest average contamination factor of 4.01 in Cd, indicates moderate contamination in the soil. $\mathrm{Cu}$ has the value of 3.437, which indicates slight contamination, $\mathrm{Cr}$ and $\mathrm{Ni}$ have average values of 1.866 and 1.531, which indicate suspected contamination in the soil. But $\mathrm{Pb}$ and $\mathrm{Zn}$ have values of 0.264 and 0.713 respectively, which indicates no contamination. The order of contamination factors is; $\mathrm{Cd}>\mathrm{Cu}>\mathrm{Cr}>\mathrm{Ni}>\mathrm{Zn}>\mathrm{Pb}$.

\section{Contamination Factor (CF) In Biogbolo Waste Dump Site}

The contamination factors of metals in Biogbolo waste dump site are shown in Table 12. The contamination factors of $\mathrm{Zn}$ and $\mathrm{Cu}$ were 2.755 and 2.764, indicating slight contamination; $\mathrm{Cd}$ (2.083), $\mathrm{Ni}$ (2.085) and $\mathrm{Cr}$ (1.734) indicate suspected contamination, $\mathrm{Pb}$ shows no contamination.

Table12. The contamination factor (CF) of the abandoned waste dump sites

\begin{tabular}{lllllll}
\hline $\begin{array}{l}\text { Sampling } \\
\text { Point }\end{array}$ & $\mathbf{C d}$ & $\mathbf{C u}$ & $\mathbf{P b}$ & $\mathbf{N i}$ & $\mathbf{C r}$ & $\mathbf{Z n}$ \\
$\begin{array}{l}\text { Etegwe } \\
\begin{array}{l}\text { Mean } \\
\text { Azikoro }\end{array}\end{array}$ & 3.926 & 2.923 & 0.323 & 1.187 & 2.027 & 3.062 \\
$\begin{array}{l}\text { Mean } \\
\text { Biogbolo }\end{array}$ & 4.01 & 3.437 & 0.264 & 1.531 & 1.866 & 0.713 \\
Mean & 2.083 & 2.764 & 0.881 & 2.085 & 1.734 & 2.755 \\
\hline
\end{tabular}

\section{Pollution Load index in Etegwe abandoned waste dump sites}

The soil from the Etegwe dump site is polluted because it gave PLI value range of 1.783 to 1.808 (Table 13), which is higher than 1. 


\section{Pollution Load Index in Azikoro Village Abandoned Waste Dump Site}

The calculated PLI values of Azikoro village dump site have the range of 1.368 to 1.439 (Table 13), which signifies pollution occurrence in the soil.

\section{Pollution Load index in Biogbolo abandoned waste dump site}

Based on the data provided in Table 13, the PLI value is higher than 1 which indicates pollution.

Table 13. Pollution Load indices of the abandoned waste dump sites

\begin{tabular}{|c|c|c|c|c|c|c|c|c|}
\hline \multirow{2}{*}{$\begin{array}{l}\text { Sampling } \\
\text { Point }\end{array}$} & \multicolumn{6}{|c|}{ Element } & \multirow[t]{2}{*}{ PLI } & \multirow{2}{*}{$\begin{array}{l}\text { Pollution } \\
\text { evaluation }\end{array}$} \\
\hline & Cd & $\mathbf{C u}$ & $\mathbf{P b}$ & $\mathbf{N i}$ & $\mathbf{C r}$ & $\mathbf{Z n}$ & & \\
\hline \multicolumn{9}{|c|}{ Etegwe abandoned waste dump site } \\
\hline EP 1 & 3.468 & 3.173 & 0.268 & 1.685 & 1.971 & 3.33 & 1.783 & Polluted \\
\hline EP 2 & 4.343 & 2.695 & 0.363 & 0.482 & 2.066 & 2.673 & 1.495 & Polluted \\
\hline EP 3 & 3.968 & 2.902 & 0.339 & 1.395 & 2.046 & 3.183 & 1.808 & Polluted \\
\hline \multicolumn{9}{|c|}{ Azikoro abandoned waste dump site } \\
\hline AC1 & 4.843 & 3.956 & 0.265 & 1.524 & 1.886 & 0.453 & 1.368 & Polluted \\
\hline AC2 & 3.406 & 3.021 & 0.232 & 1.509 & 1.923 & 0.824 & 1.335 & Polluted \\
\hline AC3 & 3.781 & 3.336 & 0.295 & 1.56 & 1.789 & 0.864 & 1.439 & Polluted \\
\hline \multicolumn{9}{|c|}{ Biogbolo abandoned waste dump site } \\
\hline BW 1 & 2.156 & 2.576 & 0.714 & 1.336 & 1.671 & 2.665 & 1.689 & Polluted \\
\hline BW 2 & 1.218 & 2.956 & 1.169 & 1.617 & 1.704 & 2.728 & 1.774 & Polluted \\
\hline BW 3 & 2.875 & 2.76 & 0.76 & 1.217 & 1.828 & 2.873 & 1.833 & Polluted \\
\hline
\end{tabular}

Replicates sampling sites of Etegwe: EP 1, EP 2, and EP 3; replicates sampling sites of Azikoro: AC 1, AC 2, and AC 3; Replicates sampling sites of Biogbolo: BW 1, BW 2, and BW 3

\section{POTENTIAL ECOLOGICAL RISK COEFFICIENT AND POTENTIAL ECOLOGICAL INDEX}

The potential ecological risk $\left(R_{i}\right)$ posed by heavy metals in soil was estimated by using the method developed by (Hakanson 1980 ).

The criteria for assessment is tabulated in Table 4. The calculated average ecological risk coefficient $\left(E_{r}^{i}\right)$ for Cd was $51.21($ Table 14), which is higher than 40 , indicating moderate ecological risk level. The $E_{r}^{i}$ of $\mathrm{Cu}, \mathrm{Pb}, \mathrm{Ni}, \mathrm{Cr}$ and $\mathrm{Zn}$ are $15.67,1.36$,

\section{Heavy Metal Potential Ecological Risk Coefficient $\left(E_{r}^{i}\right)$ and Potential Ecological Index in Etegwe Waste Dump Site}

The $E_{r}^{i}$, for Cd was 117.79 (Table 14), indicating considerable ecological risk level in the soil, but $\mathrm{Cu}, \mathrm{Pb}, \mathrm{Ni}, \mathrm{Cr}$ and $\mathrm{Zn}$ have average values that ranged from 1.61 to 14.61 , indicating no ecological or low ecological risk level. Potential ecological index of the surface soil for Etegwe was 147.06, indicating that the soil poses low ecological risk level according to the data in Table 4. The ecological risk level in single metals are; $\mathrm{Cd}>\mathrm{Cu}>\mathrm{Ni}>\mathrm{Cr}>\mathrm{Zn}>\mathrm{Pb}$. 


\section{Heavy Metal Potential Ecological Risk Coefficient $\left(E_{r}^{i}\right)$ and Potential Ecological Index in Azikoro Village Abandoned Waste}

\section{Dump Site}

The potential ecological risk coefficient were found in the following order: $\mathrm{Cd}>\mathrm{Cu}>\mathrm{Ni}>\mathrm{Cr}>\mathrm{Pb}>\mathrm{Zn}$ (Table 14). The $E_{r}^{i}$ values of all sample points were less than $40 \mathrm{in} \mathrm{Cu}, \mathrm{Ni}, \mathrm{Cr}, \mathrm{Pb}$ and $\mathrm{Zn}$ (low risk), except $\mathrm{Cd}$ that was higher than 80 and average of 120.27, which is placed in considerable ecological risk level. The values of $R_{i}$ in the soil of AC 2 and AC 3 of the sampling points were 130.50 and 143.73 respectively, representing low ecological risk, but $R_{i}$ in AC 1 in the sampling point have 178.15, indicating moderate ecological risk. The average value of $R_{i}$ in the dump site is 150.80 (moderate).

\section{Heavy Metal Potential Ecological Risk Coefficient $\left(E_{r}^{i}\right)$ and Potential Ecological Index in Biogbolo Waste Dump}

The average potential ecological risk coefficients $\left(E_{r}^{i}\right)$ for $\mathrm{Cu}, \mathrm{Ni}, \mathrm{Pb}, \mathrm{Cr}$ and $\mathrm{Zn}$ were less than 40 (Table 14), indicating low ecological risk, but the value for $\mathrm{Cd}$ was 62.49 in average indicating moderate ecological risk in the soil. The $R_{i}$ have an average value of 93.84, indicating considerable ecological risk in the soil. The order of $E_{r}^{i}$ were found as $\mathrm{Cd}>\mathrm{Cu}>\mathrm{Ni}>\mathrm{Pb}>\mathrm{Cr}>\mathrm{Zn}$.

Table 14. Heavy metal Potential Ecological Risk Coefficient $\left(E_{r}^{i}\right)$ and Potential Ecological Index of abandoned waste dump sites

\begin{tabular}{llllllll}
\hline $\begin{array}{l}\text { Sampling } \\
\begin{array}{l}\text { Point } \\
\text { Etegwe }\end{array}\end{array}$ & $\mathbf{C d}$ & $\mathbf{C u}$ & $\mathbf{P b}$ & $\mathbf{N i}$ & $\mathbf{C r}$ & $\mathbf{Z n}$ & \multicolumn{2}{c}{$\mathbf{R i}$} \\
$\begin{array}{l}\text { Mean } \\
\begin{array}{l}\text { Azikoro } \\
\text { Mean }\end{array}\end{array}$ & 117.79 & 14.61 & 1.61 & 5.93 & 4.05 & 3.06 & 147.06 \\
$\begin{array}{l}\text { Biogbolo } \\
\text { Mean }\end{array}$ & 120.27 & 17.13 & 1.31 & 7.65 & 3.72 & 0.71 & 150.80 \\
\hline
\end{tabular}

\section{Geo-accumulation index in Etegwe abandoned waste dump site}

The surface soil of Etegwe waste dump can be classified unpolluted to moderate polluted because the geo-accumulation index value of $\mathrm{Cd}, \mathrm{Cu}, \mathrm{Zn}$ and $\mathrm{Cr}$ ranged from $0.356-1.533$ with an average value ranging from $0.421-1.382$. The geo-accumulation index value for $\mathrm{Pb}$ and $\mathrm{Ni}$ were negative indicating un-pollution (Table 15).

\section{Geo-Accumulation Index in Azikoro Village Abandoned Waste Dump Site}

The soil from Azikoro village abandoned waste dump was unpolluted with $\mathrm{Cd}, \mathrm{Cu}, \mathrm{Ni}$ and $\mathrm{Cr}$ because the average geo-accumulation index values ranged from 1.259 and 1.187 (Table 15). $\mathrm{Ni}$ and $\mathrm{Cr}$ have average values of 0.032 and 0.315 , which indicates unpolluted state of the soil. $\mathrm{Pb}$ and $\mathrm{Zn}$ have negative geo-accumulation values (-2.509 and - 1.187), indicating unpolluted soil. 


\section{Geo-Accumulation Index in Biogbolo Waste Dump Site}

The soil from the Biogbolo waste dump was not polluted with $\mathrm{Cd}, \mathrm{Cu}, \mathrm{Cr}, \mathrm{Zn} \mathrm{Pb}$ and $\mathrm{Ni}$ because they respectively have average geoaccumulation index values of $0.476,0.879,-0.803,-0.120,0.208$ and 0.877 ; values less than 1 (Table 15) The Geo-Accumulation Index values show no pollution to slight pollution of the soils.

Table 15. Geo-accumulation index of abandoned waste dump sites

\begin{tabular}{|c|c|c|c|c|c|c|}
\hline \multirow{2}{*}{ Sampling Point } & \multicolumn{4}{|c|}{ Igeo } & \multirow[b]{2}{*}{$\mathrm{Cr}$} & \multirow[b]{2}{*}{$\mathbf{Z n}$} \\
\hline & Cd & $\mathbf{C u}$ & $\mathbf{P b}$ & $\mathrm{Ni}$ & & \\
\hline Etegwe & & & & & & \\
\hline $\begin{array}{l}\text { Mean } \\
\text { Azikoro }\end{array}$ & 1.382 & 0.958 & -2.224 & -0.525 & 0.421 & 1.024 \\
\hline $\begin{array}{l}\text { Mean } \\
\text { Biogbolo }\end{array}$ & 1.259 & 1.187 & -2.509 & 0.032 & 0.315 & -1.187 \\
\hline Mean & 0.476 & 0.879 & -0.803 & -0.120 & 0.208 & 0.877 \\
\hline
\end{tabular}

\section{Nemerow Multi-Factor Values For Etegwe abandoned Waste Dump Site}

The Etegwe waste dump is moderately polluted in the overall categorization of pollution, 2.37 being the average Nemerow multifactor (Table 16). The values in table show that the soil is severely polluted with $\mathrm{Cd}(4.13), \mathrm{Zn}(3.19)$, and $\mathrm{Cu}$ (3.05); moderately polluted with $\mathrm{Cr}$ (2.04); slightly polluted with $\mathrm{Ni}$ (1.45). The soil is contaminated with $\mathrm{Pb}$ at save level.

\section{Nemerow Multi-Factor Value for Azikoro Village abandoned Waste Dump Site}

Nemerow Multi-factors, $P_{C}$ of metals show the soil from Azikoro village waste dump site is seriously contaminated with $\mathrm{Cd}\left(P_{C}\right.$ ,4.44), $\mathrm{Cu}\left(P_{C}, 3.70\right)$; slightly contaminated with $\mathrm{Cr}\left(P_{C}, 1.89\right)$ and $\mathrm{Ni}\left(P_{C}, 1.54\right)$. The site only contaminated at save level with $\mathrm{Pb}$ and Zn (Table 16).

\section{Nemerow Multi-Factor Values For Biogbolo Waste Dump Site}

The average Nemerow multifactor $\left(P_{C}\right)$ is 2.14 for the Biogbolo waste dump site, which indicate moderate contamination in the soil. At individual metal level, the soil is moderately contaminated with $\mathrm{Cu}\left(P_{C}, 2.86\right), \mathrm{Zn}\left(P_{C}, 2.81\right)$ and $\mathrm{Cd}\left(P_{C}, 2.51\right)$; slightly contaminated with $\mathrm{Ni}\left(P_{C}, 1.86\right), \mathrm{Cr}\left(P_{C}, 1.78\right)$ and $\mathrm{Pb}\left(P_{C}, 1.03\right)$ (Table 16).

Table 16.Nemerow Multi-factor values of abandoned waste dump sites

\begin{tabular}{llll}
\hline Elements & Pc & Contamination level & Contamination degree \\
\hline Etegwe waste dump site & & \\
$\mathrm{Cd}$ & 4.13 & Severely Contaminated & Severely contaminated \\
$\mathrm{Cu}$ & 3.05 & Severely & Severely contaminated \\
$\mathrm{Pb}$ & 0.34 & Save & Clean \\
$\mathrm{Ni}$ & 1.45 & Light Contaminated & Soil slightly contaminated \\
$\mathrm{Cr}$ & 2.04 & Moderate & Moderately contaminated \\
$\mathrm{Zn}$ & 3.19 & Severely & Severely contaminated \\
Average & 2.37 & Moderate & Moderately contaminated \\
\hline
\end{tabular}




\begin{tabular}{llll}
\hline \multicolumn{2}{l}{ Azikoro waste dump site } & & \\
$\mathrm{Cd}$ & 4.44 & Severe & Seriously contaminated \\
$\mathrm{Cu}$ & 3.70 & Severe & Seriously contaminated \\
$\mathrm{Pb}$ & 0.27 & Save & Clean \\
$\mathrm{Ni}$ & 1.54 & Light & Slightly contaminated \\
$\mathrm{Cr}$ & 1.89 & Light & Slightly contaminated \\
$\mathrm{Zn}$ & 0.79 & Save & Clean \\
Average & 2.10 & Light & Slightly contaminated \\
$\mathrm{Biogbolo}$ & waste dump site & & \\
$\mathrm{Cd}$ & 2.51 & Moderate & Soil moderately contaminated \\
$\mathrm{Cu}$ & 2.86 & Moderate & Soil moderately contaminated \\
$\mathrm{Pb}$ & 1.03 & light & Soil slightly contaminated \\
$\mathrm{Ni}$ & 1.86 & Light & Soil slightly contaminated \\
$\mathrm{Cr}$ & 1.78 & Light contamination & Soil slightly contaminated \\
$\mathrm{Zn}$ & 2.81 & moderate & Soil moderately contaminated \\
$\mathrm{Average}$ & 2.14 & moderate & Soil moderately contaminated \\
\hline
\end{tabular}

\section{Pollution Contamination Index in Etegwe Waste Dump Site}

The results of the pollution contamination index study for the Etegwe waste dump site are shown in Table 17. The soil can be classified as moderately polluted because it has an average $\mathrm{Cp}$ of 2.49 . Based on the $\mathrm{Cp}$ values, the soil is not polluted with $\mathrm{Pb}(\mathrm{Cp}$, 0.36); moderately polluted with $\mathrm{Zn}(\mathrm{Cp}, 3.33)$ and $\mathrm{Cu}(\mathrm{Cp}, 3.17)$; severely polluted with $\mathrm{Cd}(\mathrm{Cp}, 4.34)$. The order of pollution contamination indices is: $\mathrm{Cd}>\mathrm{Zn}>\mathrm{Cu}>\mathrm{Cr}>\mathrm{Ni}>\mathrm{Pb}$.

\section{Pollution Contamination Index in Azikoro Village Abandoned Waste Dump Site}

The comprehensive pollution contamination index of metals from Azikoro village abandoned waste dump site was 2.06 (Table 17), indicating moderate level of pollution of the site. However, the site is severely polluted with $\mathrm{Cu}(\mathrm{Cp}, 3.95), \mathrm{Cd}(\mathrm{Cp}, 3.78)$ and $\mathrm{Cr}(\mathrm{Cp}$, 1.92); moderately polluted with $\mathrm{Ni}(\mathrm{Cp}, 1.56)$ but the soil is not polluted with $\mathrm{Zn}(\mathrm{Cp}, 0.86)$ and $\mathrm{Pb}(\mathrm{Cp}, 0.29)$. The order of pollution is: $\mathrm{Cd}>\mathrm{Cu}>\mathrm{Cr}>\mathrm{Ni}>\mathrm{Zn}>\mathrm{Pb}$.

\section{Pollution Contamination Index in Biogbolo Waste Dump Site}

The overall assessment result for the pollution contamination index in Biogbolo waste dump site showed an average value of 2.21 (Table 17), indicating moderate pollution. The pollution contamination index for $\mathrm{Cd}, \mathrm{Cu}, \mathrm{Ni}, \mathrm{Cr}$ and $\mathrm{Zn}$ were $2.87,2.95,1.61,1.82$ and 2.86 respectively, indicating moderate pollution. The order of pollution contamination index is: $\mathrm{Cu}>\mathrm{Cd}>\mathrm{Zn}>\mathrm{Cr}>\mathrm{Ni}>\mathrm{Pb}$.

Table 17.Pollution Contamination indices of abandoned waste dump sites

\begin{tabular}{lll}
\hline Elements & Cp value & Pollution level \\
\hline Etegwe abandoned waste dump site & & \\
$\mathrm{Cd}$ & 4.34 & Very Severe pollution \\
$\mathrm{Cu}$ & 3.17 & Severe pollution \\
$\mathrm{Pb}$ & 0.36 & Not pollution \\
$\mathrm{Ni}$ & 1.68 & Moderate pollution \\
$\mathrm{Cr}$ & 2.06 & Moderate pollution \\
$\mathrm{Zn}$ & 3.33 & Severe pollution \\
\hline \multicolumn{3}{c}{ (C) 2018, Scientific Research Journal } \\
\multicolumn{3}{c}{ http://dx.doi.org/10.31364/SCIRJ/v6.i10.2018.P1118577 } \\
\end{tabular}




\begin{tabular}{lll}
\hline Average & 2.49 & Moderate pollution \\
Azikoro abandoned waste dump site & & \\
$\mathrm{Cd}$ & 3.78 & Severe pollution \\
$\mathrm{Cu}$ & 3.95 & Severe pollution \\
$\mathrm{Pb}$ & 0.29 & Not polluted \\
$\mathrm{Ni}$ & 1.56 & Moderate pollution \\
$\mathrm{Cr}$ & 1.92 & Moderate pollution \\
$\mathrm{Zn}$ & 0.86 & Not polluted \\
Average & 2.06 & Moderate pollution \\
$\mathrm{Biogbolo}$ abandoned waste dump site & & \\
$\mathrm{Cd}$ & 2.87 & Moderate pollution \\
$\mathrm{Cu}$ & 2.95 & Moderate pollution \\
$\mathrm{Pb}$ & 1.16 & Low pollution \\
$\mathrm{Ni}$ & 1.61 & Moderate pollution \\
$\mathrm{Cr}$ & 1.82 & Moderate pollution \\
$\mathrm{Zn}$ & 2.86 & Moderate pollution \\
$\mathrm{Average}$ & 2.21 & Moderate pollution \\
\hline
\end{tabular}

\section{MODIFIED DEGREES OF CONTAMINATION (mCdi) AND CONTAMINATION DEGREE INDEX (Cdi)}

The modified degrees of contamination and contamination degree index values for heavy metals in the sites under investigation are given in Table 18. Modified Degree of Contamination and Contamination Degree Index in Etegwe Dump Site

Results of the Cdi and mCdi assessments are given in Table 18. The modified degree of contamination varied from 1.30 to 2.31 with an average value of 1.90 , indicating a low degree of pollution. The contamination degree index varied from 12.62 to 13.89 , with an average value of 13.44 , representing a considerable degree of pollution.

\section{Modified Degree of Contamination and Contamination Degree Index in Azikoro Village Abandoned Waste Dump Site}

The Azikoro village abandoned waste dump sites can be assessed to be moderately polluted with the metals of interest because the Cdi values varied from 10.91 to 12.92 with an average value of 11.81 (Table 18) but the site can be categorized low degree of pollution mCdi values of the metals ranged from 1.93 to 2.15 with an average of 1.96 .

\section{Modified Degree of Contamination and Contamination Degree Index in Biogbolo Waste Dump Site}

The Biogbolo waste dump site is moderately polluted as evident in the Cdi values that ranged from 11.11 to 12.31 with an average value of 11.60 (Table 18), the mCdi values, ranging from 1.85 to 2.05 with an average value of 1.93 , indicating a low degree of pollution.

Table 18. Modified degree of contamination and contamination degree index of abandoned waste dump sites

\begin{tabular}{|c|c|c|c|c|c|c|}
\hline Sampling & Elem & & & & & \\
\hline Point & Cd & $\mathrm{Cu}$ & $\mathbf{P b}$ & $\mathbf{N i}$ & $\mathrm{Cr}$ & Zn \\
\hline Etegwe ab & loned & dump & & & & \\
\hline EP 1 & 3.46 & 3.17 & 0.26 & 1.68 & 1.97 & 3.33 \\
\hline EP 2 & 4.34 & 2.69 & 0.36 & 0.48 & 2.06 & 2.67 \\
\hline
\end{tabular}




\begin{tabular}{|c|c|c|c|c|c|c|c|c|}
\hline EP 3 & 3.96 & 2.90 & 0.33 & 1.39 & 2.04 & 3.18 & 13.83 & 1.30 \\
\hline \multicolumn{9}{|c|}{ Azikoro abandoned waste dump site } \\
\hline $\mathrm{AC} 1$ & 4.84 & 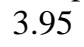 & 0.26 & 1.52 & 1.88 & 0.45 & 12.92 & 2.15 \\
\hline $\mathrm{AC} 2$ & 3.40 & 3.02 & 0.23 & 1.50 & 1.92 & 0.82 & 10.91 & 1.81 \\
\hline $\mathrm{AC} 3$ & 3.78 & 3.33 & 0.29 & 1.56 & 1.78 & 0.86 & 11.62 & 1.93 \\
\hline \multicolumn{9}{|c|}{ Biogbolo abandoned waste dump site } \\
\hline BW 1 & 2.15 & 2.57 & 0.71 & 1.33 & 1.67 & 2.66 & 11.11 & 1.85 \\
\hline BW 2 & 1.21 & 2.95 & 1.16 & 1.61 & 1.70 & 2.72 & 11.39 & 1.89 \\
\hline BW 3 & 2.87 & 2.76 & 0.76 & 1.21 & 1.82 & 2.87 & 12.31 & 2.05 \\
\hline
\end{tabular}

Replicates sampling sites of Etegwe: EP 1, EP 2, and EP 3; replicates sampling sites of Azikoro: AC 1, AC 2, and AC 3; Replicates sampling sites of Biogbolo: BW 1, BW 2, and BW 3

\section{Enrichment Factor in Etegwe Waste Dump Site}

The enrichment factors of metals for the Etegwe site are shown in Table 19. The EF values show that the soil is significantly enriched (EF greater than 5) with $\mathrm{Cd}, \mathrm{Cu}$, and $\mathrm{Zn}$; moderately enriched with $\mathrm{Cr}$ and $\mathrm{Ni}$ but not enriched (EF, 0.732) with $\mathrm{Pb}$. The order of enrichment factors is: $\mathrm{Cd}>\mathrm{Zn}>\mathrm{Cu}>\mathrm{Cr}>\mathrm{Ni}>\mathrm{Pb}$.

\section{Enrichment Factor in Azikoro Village Abandoned Waste Dump Site}

The average enrichment factors for metals in Azikoro waste dump site ranged from 0.681 to 9.572 (Table 19). The EF values indicate that the soil is significantly enriched with $\mathrm{Cd}(\mathrm{EF}, 9.281), \mathrm{Cu}(\mathrm{EF}, 9.572)$, and $\mathrm{Cr}$ (EF, 5.232); moderately enriched with $\mathrm{Ni}(\mathrm{EF}$, 4.000) and $\mathrm{Zn}$ (EF, 2.089); not enriched with $\mathrm{Pb}(\mathrm{EF}, 0.681)$.

\section{Enrichment Factor in Biogbolo Waste Dump Site}

The average $\mathrm{EF}$ values of $\mathrm{Cd}, \mathrm{Cu}, \mathrm{Pb}, \mathrm{Ni}, \mathrm{Cr}$ and $\mathrm{Zn}$ were 4.789, 6.470, 2.051, 3.273, 4.063 and 6.460 respectively (Table 19); ordered as follows: $\mathrm{Cu}>\mathrm{Zn}>\mathrm{Cd}>\mathrm{Cr}>\mathrm{Ni}>\mathrm{Pb}$. From the assessment of the enrichment factors, the soil is significantly enriched with $\mathrm{Cu}$ and $\mathrm{Zn}$; moderately polluted with $\mathrm{Pb}$ and $\mathrm{Ni}$.

Table 19. Enrichment factor of abandoned waste dump sites

\begin{tabular}{|c|c|c|c|c|c|c|}
\hline \multirow[t]{2}{*}{ Sample point } & \multicolumn{4}{|c|}{$\mathrm{EF}$} & \multirow[b]{2}{*}{$\mathrm{Cr}$} & \multirow[b]{2}{*}{$\mathbf{Z n}$} \\
\hline & Cd & $\mathrm{Cu}$ & $\mathbf{P b}$ & $\mathbf{N i}$ & & \\
\hline $\begin{array}{l}\text { Mean } \\
\text { Azikoro }\end{array}$ & 8.907 & 6.649 & 0.732 & 2.700 & 4.604 & 6.958 \\
\hline $\begin{array}{l}\text { Mean } \\
\text { Biogbolo }\end{array}$ & 9.281 & 9.572 & 0.681 & 4.000 & 5.232 & 2.089 \\
\hline Mean & 4.789 & 6.470 & 2.051 & 3.273 & 4.063 & 6.460 \\
\hline
\end{tabular}

\section{Conclusion}

Having a good knowledge of the quality of soil prior to the commencement of farming cannot be over-emphasized. Potential farmlands (abandoned waste dumpsites in Yenagoa metropolis) were assessed for quality for potential farming activities and the pollution indices (contamination factor (CF), degrees of ecological risk, Potential Contamination index, Modified degree of 
contamination, Enrichment factor, geo-accumulation index, Nemerow multi-factor) show that the abandoned dumpsites are only slightly polluted with $(\mathrm{Cd})$ and may not pose health threats to man when used for farming. The low level of pollutions is also consistent with the low level of industrialization of the state.

\section{Reference}

Abrahim G.M.S and Parker R.J (2008). Assessment of heavy metals enrichment factor and the degree of contamination in marine sediments from Tamaki Estuary, Auckland, New Zealand. Environ. Monit. Assess. 136: 227 - 238.

CEVIK F., GÖKSU M.Z.L., DERICI OB, FINDIK O. (2009). An assessment of metal pollution in surface sediments of Seyhan dam by using enrichment factor, geoaccumulation index and statistical analyses. Environ. Monit Assess 152: 309317.

Dauvalter V. and Rognerud S. (2011). Heavy metal pollution in sediments of the Pasvik River drainage. Chemosphere, 42: 9 - 18.

Fytianos K., Katsianis G., Trianta-Fyllou P., And Zachariadis G. (2001). Accumulation in heavy metals in vegetables grown in an industrial area in relation to soil. Bulletin of Environmental contamination and Toxicology, 67(3): pp. 423 - 430.

Ghrefat $\mathrm{H}$ and Yosuf N. (2006). 'Assessing Mn, Fe, Cu, Zn and Cd Pollution in Bottom Sediments of Wadi, Al-Arab Dam, Jorn,' Chemosphere, 65 (11): 2114 - 2121.

Gonzoles-Macias C., Schifter I., Liuch-Costal Db, Mendez-Rodriquez L., Hernandez-Vazquez S (2006). Distribution, enrichment and accumulation of heavy metals in costal sediments of Salina Cruz Bay, Mexico. Environ Monit Assess 118: 211 - 230.

Hakanson L. (1980). An ecological risk index for aquatic pollution control, a sedimentological approach. Water Research. 14: 975 - 1001.

Hinojosa M.B., Carreira J.A., Ruiz R.G., and Dick R.P., (2014). Soil moisture pretreatment effects on enzyme activities as indicators of heavy metal contaminated and reclaimed soils. Soil Biology \& Biochemistry, 36: 1559 - 1568.

Homa J, Niklinska M, and Plytycz B. (2003). Effect of heavy metals on coelomocytes of the earthworm Allolobophora chlorotica. Pedobiologia, 47: 640 - 645.

Jordao CP, Fialho LL, Neves JCL, Cecon PR, Mendonca ES and Fontes RLF (2007). Reduction of heavy metal contents in Liquid effluents by vermicomposts and the use of the metal-enriched vermicomposts in lettuce cultivation. Bioresource Technology. 98 (15): 2800 - 2813.

Khan S, Cao O, Zheng Y.M, Huang Y.Z, and Zhu Y.G (2008). Health risk of heavy metals in contaminated soil and food crops irrigated with waste water in Beijing, China. Environmental Pollution Series, 1529 (3), 686 - 692.

Kwokal Z, Franciskovic-Bilinski S, Bilinski H, Branica M (2002). A comparison of anthropogenic mercury pollution in Kastela Bay (Croatia) with pristine estuaries in Ore (Sweden) and Krka (Croatia), Mar Pollut Bull 44: 1152 - 1169.

Liu WX, Li XD, Shen ZG, Wang DC, Wadi OWH, Li YS (2003). Multivariates statistical study of heavy metals enrichment in sediments of the Pearl River Estuary. Environ Pollut. 121(3): 377 388.

Lourĩno-Cabana B, Lesven L, Charrian A., Billon G., Baghdad O., Boughriet A. (2011). Potential risks of metal toxicity in contaminated sediments of Deûle River in Northern France. Journal of hazard Mater 186: 2129 - 2137

Lu C.A., Zhang J.F., Jiang H.M., Yang Y.C., Zhang J.T., Wang J.Z And Shan H.X (2010). Assessment of soil contamination with $\mathrm{Cd}, \mathrm{Pb}$ and $\mathrm{Zn}$ and source identification in the area around the Huludao Zinc plant. J. Hazard Mater, 182: 743 - 748.

Luo W., Lu Y., Giesy J.P, Wang T., Shi Y., Wang G. and Xing Y (2007). Effects on land use on concentrations of metals in surface soils and ecological risk around Granting reservoir, China. Environ. Geochem. Health, 29: 459 - 471.

Luo W., Lu Y., Giesy J.P, Wang T., Shi Y., Wang G. and Xing Y (2007). Effects on land use on concentrations of metals in surface soils and ecological risk around Granting reservoir, China. Environ. Geochem. Health, 29, 459 - 471.

Luo W., Wang T.Y., Lu Y.L., Giesy J.P., Shi Y.J., Zheng Y.M., Xing Y., Wu G.H (2007). Landscape ecology of the granting reservoir. Beijing. China: multivariate and geostatistical 
analysis of metals in soils. Environ. Pollution, 146: 567 - 576.

Maanan M., Saddik M., Maanan M., Chaibi M., Assobhei O., Zourarah B (2014). Environment and ecological risk assessment of heavy metals in sediments of Nador lagoon, Morocco. Ecological Indicators, 48: 616 - 626.

Muller G. (1969). Index of geo-accumulation in sediments of the Rhine river. Geology journal, 2(3): $109-118$.

Ndiwarri E.L (2004). Road network analysis for Yenagoa Local Government Area, Bayelsa State. Unpublished thesis, Federal School of Surveying Oyo. Oyo State 1-3.

Pastor J. and Hernandez A.J (2012). Heavy metal salts and organic residues in old solid urban waste landfills and surface waters in their discharge areas; determinant for restoring their impact, Journal of Environment Management, 95: S42 - S49.

Rascio N, Navari-Izzo F (2011) Heavy metal hyper-accumulating plants; how and what do they do it? And what makes them so interesting? Plant Sci. (Shannon Ireland) 180: 160 - 180.

Scazzola R., Avezzu S., Biancotto R., Chiameuti E., Chiozzotto E., Gerotto M., Palonta M, And Roiter S. (2003). Assessment of heavy metal background values in the soils of inland coastal areas of venice, Italy. Ann. Chim., 93: 465 - 470.

Soldecilla M., Maranon T., Cabbrera F. (1992). Heavy metal content in soil and plants from a pyrite mining area in southwest Spain, Communications In Soil And Plant Analysis, 23(11-12), 1301-1319.

Stafilov T., Sajn R., PančEvsk Z., Boev B., Frontasyeva M.V. And Strelkova L.P. (2010). Heavy metal contamination around a lead and zinc smelter, Republic of Macedonia. J. hazard Mater, 175: 895 - 914.

Sukkariyah B.F., Evanylo G., Zelazuy L. and Chaney R.L (2005). Recovery and distribution of biosolids-derived trace metals in clay loam soil. Journal of Environmental Quality, 34 (5): 1843 1850 .

Taylor S.R and Mclennan S.M (1995). The geochemical evolution of the continental crust. Rev. Geophys., 33, 241 - 265.

Wu Yao-Guo, Xu You-Ning, Zhang Jiang-Hua, Hu Si-Hai (2010). Evaluation of ecological risk and primary empirical research on heavy metals in polluted soil over Xiaoqinling gold mining region, Shaanxi, China. [J]. Transactions of Nonferrous Metals Society of China, 20: 688 - 694.

Yang Z.F., Wang Y., Shen Z.Y., Niu J.F., Tang Z.W. (2011). Distributon and speciation of heavy metals in sediments from mainstream, tributaries, and lakes of the Yangtze River catchment of Wuhan, China. Journal of hazard mater, 66, 1186-1194.

You H., Xu J., and Huang C (2003). Substrate utilization pattern, biomass and activity of microbial communities in a sequence of heavy metal polluted paddy soils. Geoderma, 115: 139 148.

Yu R., Yuan X., Zhao Y, Hu G., Xiang-Lin T. (2008). Heavy metal pollution in intertidal sediments from Quanzhou Bay, China. Journal of Environmental Scienc, 20 (6): 664 - 669.

Zhang W, Feng H, Chang J, Qu J, Xie H, Yu L (2009). Heavy metal contamination in surface sediments of Yangtze River intertidal zone: an assessment from different indexes. Environ Pollution 157: 1533 - 1543. 